\title{
Swa-radikalisasi Melalui Media Sosial di Indonesia
}

\author{
Achmad Sulfikar \\ Dosen Institut Agama Islam Negeri (IAIN) Palopo \\ Email : rafiklus@gmail.com
}

\begin{abstract}
Abstrak
Revolusi teknologi komunikasi dan informasi selalu melahirkan format komunikasi yang berbeda dari yang pernah ada. Interaksi antar manusia yang sebelumnya dibatasi oleh ruang dan pertemuan secara fisik kini dapat dilakukan tanpa batas, menembus batasbatas kota dan negara. Kehadiran beragam aplikasi media sosial berbasis online memberi ruang dan peluang tak terbatas bagi pengguna internet di Indonesia untuk bertukar informasi. Hal ini kemudian dimanfaatkan oleh politisi untuk melakukan kampanye, propaganda bahkan agitasi. Tidak hanya politisi, kelompok Islam garis keras juga memanfaatkan sosial media sebagai wahana penyebarluasan pesan-pesan yang mengandung kekerasan. Swa-radikalisasi adalah fenomena yang menyusul penggunaan media sosial untuk tujuan kekerasan. Berbeda dengan radikalisasi, swa-radikalisasi timbul karena ada unsur kesengajaan pelaku dalam aktifitasnya di dunia maya. Ia mencari sendiri sumber-sumber informasi yang memuat pesan-pesan yang menguatkan potensi radikal dalam dirinya. Pesan-pesan yang kemudian dikonsumsi tidak hanya sebatas pada ide dan tetapi juga hal yang bersifat praktis seperti cara membuat bahan peledak rakitan. Ujung dari proses swa-radikalisasi melalui media sosial ini sendiri tidak lebih baik, ia akan menciptakan lone-wolf terrorist, teroris yang bergerak sendiri tanpa perintah, tanpa organisasi, dan sulit dideteksi yang akan merusak kehidupan masyarakat secara mental dan fisik.
\end{abstract}

Keywords: radikalisme, terorisme, internet, media sosial. 


\section{Pendahuluan}

Saat ini manusia berada pada era kelimpahan informasi. Era ini ditandai dengan banyaknya informasi melalui berbagai saluran komunikasi yang dimiliki oleh warga, mulai dari media mainstream hingga media sosial. Penetrasi media sosial sendiri ke dalam ruang pribadi hampir tidak terbatas. Blumler dan Kavanagh (Ward \& Cahill, 2007) menyatakan saat ini adalah era di mana media cetak dan penyiaran mulai kehilangan posisi mereka sebagai saluran komunikasi politik terkemuka di era kelimpahan informasi. Ide, gagasan, informasi, dan berita politik disebarkan melalui media online tidak lagi dikuasai oleh media cetak. Newhagen dan Rafaeli (Wood \& Smith, 2005) mengidentifikasi dua sifat utama yang membedakan Internet dari bentuk komunikasi lain yaitu; format multi media dan adanya interaktivitas.

Sebagaimana saluran komunikasi yang ada sebelumnya, internet juga memiliki sisi baik dan buruk. Jika pada media mainstream kedua sisi ini ditentukan oleh banyak orang atau institusi, maka pada internet sisi baik dan buruk ini ditentukan oleh individu atau siapapun yang bisa mengakses dan menggunakannya. Pada saat yang bersamaan pesanpesan yang disebarkan melalui media online akan menyebar secara cepat dan luas sehingga kontrol terhadapnya menjadi sangat sulit. Mudah, murah, dan cepat; tiga hal yang melekat pada media online ini kemudian dimanfaatkan oleh sekelompok orang menjadikannya sebagai media propaganda untuk disebarluaskan kepada masyarakat.

Penggunaan media sosial sebagai media penyebaran pesan-pesan politik sendiri masih terbilang baru di Indonesia. Pemilihan Kepala Daerah (Pilkada) DKI Jakarta tahun 2012 adalah kali pertama media sosial di Indonesia memegang peranan penting dalam kampanye politik yang didukung oleh relawan netizen yang secara mengejutkan memenangkan pasangan Joko Widodo - Basuki Tjahaja Purnama mengalahkan petahana yang didukung oleh mayoritas partai politik (Andriadi, 2017). Sejak saat itu media sosial menempati posisi penting di panggung politik Indonesia hingga mencapai puncaknya pada Pemilihan Umum Presiden (Pilpres) tahun 2014, pasangan Jokowi-JK memenangkan pemilu yang sekali lagi didukung oleh relawan yang memanfaatkan kekuatan media sosial. 
Sejalan dengan kehadiran media sosial di Indonesia yang mudah diakses oleh semua lapisan masyarakat, beberapa kelompok mulai menggunakannya untuk tujuan politik tertentu, termasuk kelompok Islam radikal seperti; Hizbut Tahrir Indonesia, Harakah Tarbiyah, Jamaah Salafi, dan Front Pembela Islam (Muthohirin, 2015). Dalam dua dekade terakhir, gerakan-gerakan Islam radikal di Indonesia semakin meningkat di ranah publik. Meskipun upaya pencegahan dan penanggulangan sedang dilakukan oleh pemerintah, kelompok-kelompok ekstremis ini tetap bermunculan (Andriyani \& Kushindarti, 2018; Samuel, 2016; Siagian \& Sumari, 2015; Singh, 2009).

Salah satu alasan munculnya radikalisme Islam di Indonesia adalah adanya halaman online, akun media sosial, portal online dan video yang sengaja dirancang untuk menyebarkan ideologi kekerasan dan pidato kebencian, termasuk gagasan mendirikan negara Islam. Media sosial dan jaringan online sebagai sarana komunikasi massa sangat strategis karena dapat bersifat anonim, memiliki jangkauan yang luas dan juga cukup biaya rendah. Karena itu media sosial adalah pilihan praktis untuk menyebarluaskan pandangan politik dan pandangan radikal kepada siapa saja yang memiliki konektivitas dengan jaringan online.

Berdasarkan survei tentang Penetrasi dan Perilaku Pengguna Internet di Indonesia pada tahun 2017 yang dilakukan oleh Asosiasi Penyedia Layanan Internet Indonesia (APJII) menyatakan bahwa 143,26 juta $(54,68 \%)$ dari 262 juta orang Indonesia adalah pengguna internet. Kemudian ada $87,13 \%$ pengguna internet mengakses media sosial sebagai tujuan utama menggunakan internet (APJII, 2017). Dari data ini dapat disimpulkan bahwa informasi yang disebar-luaskan oleh siapa pun telah menembus ruang-ruang pribadi jutaan orang di Indonesia. Berdasarkan survei ini pula, dapat dikatakan bahwa pengguna media sosial di Indonesia adalah pasar yang sangat potensial bagi kelompok radikal yang menggunakan media sosial sebagai sarana propaganda dan penyebaran pesan yang mengandung kekerasan. 


\section{Media Sosial Sebagai Media Sebar Narasi Radikal}

Media sosial berbeda dari media tradisional dan konvensional dalam banyak aspek, seperti dalam hal interaktivitas, jangkauan, frekuensi, kegunaan, kesegeraan, dan kelanggengan. Tidak seperti media tradisional, di mana hanya sekelompok kecil lembaga-lembaga yang sudah mapan menyebarkan informasi ke khalayak yang tidak terbatas, media sosial membuat siapa pun mampu untuk mempublikasikan atau mengakses informasi. Teknologi komunikasi baru, seperti jaringan seluler dan berbasis web yang relatif murah dan mudah diakses menciptakan platform yang sangat interaktif melalui mana individu dan masyarakat berbagi, mendiskusikan, dan memodifikasi konten. Dengan media sosial konsumen informasi sekaligus bertindak sebagai produsen atau komunikator. Komunikasi dua arah ini mendorong terciptanya sekelompok komunikator dan kelompok yang kecil dan tersebar. Komunitas virtual yang menggunakan media sosial semakin populer di seluruh dunia, terutama di kalangan demografi yang berusia lebih muda.

Kelompok radikal memiliki alasan yang tepat untuk menggunakan media sosial. Pertama, saluran-saluran media sosial sejauh ini adalah paling populer dengan target yang dituju yang memungkinkan informasi dari kelompok mereka menjadi bagian dari arus utama. Kedua, saluran media sosial yang mudah digunakan dan gratis. Akhirnya, jejaring sosial memungkinkan kelompok radikal untuk menjangkau audiens target mereka menembus batas-batas fisik secara personal, berbeda dengan model lama laman web site di mana mereka harus menunggu pengunjung untuk datang kepada mereka.

Meningkatnya eksistensi kelompok-kelompok radikal di Indonesia salah satu penyebabnya utamanya juga adalah hadirnya laman-laman online, aplikasi media sosial seperti Facebook dan Twitter, aplikasi berbagi video seperti YouTube, dan aplikasi berbagi pesan dalam format beragam tetapi cenderung bersifat personal seperti Telegram dan WhatsApp. Media sosial dan jejaring online sebagai saluran komunikasi massa adalah pilihan yang sangat strategis bagi kelompok-kelompok ini karena pesan yang disebarluaskan sumbernya lebih sulit dideteksi, memiliki potensi dampak yang luas, dan biaya yang lebih murah. 
Pilihan media sosial oleh kelompok-kelompok radikal ini membuktikan kemampuan mereka untuk menggantikan peran media arus utama sebagai saluran untuk penyebaran pesan-pesan yang tidak dapat dimiliki kelompok-kelompok ini. Mereka menggunakan Internet sebagai katalis untuk kekerasan dan alat propaganda yang efektif untuk mendapatkan dukungan dari simpatisan (Candra, 2017). Bahkan, kemampuan kelompok dalam pengaruh besar banyak orang mencuri perhatian elit politik di Indonesia (IPAC, 2018). Fenomena ini menegaskan bahwa media sosial bukan hanya media untuk menghubungkan orang satu sama lain tetapi juga telah menjadi panggung politik baru bagi kelompok Islam radikal di Indonesia, kehadiran besar mereka di media sosial menciptakan kekuatan tawar mereka dalam mencapai tujuan mereka terhadap masyarakat.

Pengalaman bagaimana internet telah digunakan dan memainkan peran penting dalam propaganda radikalisme adalah sebuah kenyataan di Indonesia. Aktivis kelompok radikal telah terbukti menggunakan jaringan online untuk menyebarluaskan informasi untuk tujuan organisasi. Santoso, pimpinan Mujahidin Indonesia Timur (MIT) telah mahir menggunakan YouTube sebagai media propaganda untuk mengirim pesan yang mengandung teror dan ancaman terhadap keamanan dan pemerintah Indonesia (Ismail, 2016). Bahrun Naim, seorang anggota ISIS di Indonesia yang melakukan teror bom Sarinah juga terkenal menggunakan internet untuk menyebarkan propagandanya di Indonesia (Selamat, 2016). Hal ini menunjukkan bahwa kelompok radikal ini telah mengembangkan kemampuan untuk mentransmisikan pesan mereka secara virtual untuk memengaruhi individu dan komunitas yang ada di media sosial.

Pada dasarnya teroris juga menggunakan internet untuk beberapa alasan yang sama dilakukan orang lain; untuk komunikasi intra organisasi dan perencanaan gerakan, mendidik pengikut dan bahkan untuk hiburan. Sebagian besar topik komunikasi online para teroris adalah hal yang biasa hingga ke tingkat berbahaya (Klausen, 2015).

Karena berbagai kelebihan media sosial sehingga kegiatan kelompok ini dimulai di sana. Kohlman (Weimann, 2014) percaya saat ini sekitar 90 persen kegiatan teroris di internet terjadi menggunakan media sosial; forum ini menjadi semacam firewall virtual 
untuk membantu mereka melindungi identitas anggota grup. Selain itu, mereka menawarkan kesempatan untuk melakukan kontak langsung dengan perwakilan tokoh kunci untuk mengajukan pertanyaan bahkan untuk berkontribusi dan membantu dalam kegiatan yang mereka sebut cyber jihad (Heickerö, 2014). Media sosial yang sebelumnya menjadi media penghubung individu antar individu dan banyak orang berubah menjadi menjadi alat teror (Awan, 2017).

Pengaruh kelompok Islam radikal yang awalnya memainkan isu globaltransnasional kemudian mulai memainkan masalah-masalah lokal. Hal tersebut dapat dilihat dari desakan dan masalah yang diwakili oleh kelompok ini seperti; tuntutan atas penerapan syariah Islam dalam bentuk peraturan daerah, kewajiban untuk memilih gubernur dan walikota Muslim untuk pemilih Muslim (IPAC, 2018) dan dikotomi SunniSyiah adalah beberapa dari banyak masalah yang sedang dikendarai oleh kelompokkelompok ini. Sebagai negara yang didominasi Muslim, isu-isu ini efektif dalam menarik perhatian banyak orang dan menjadikannya sebagai topik diskusi yang menarik di media sosial. Fakta-fakta ini telah mengkonfirmasi argumen tentang glokalisasi oleh kelompok radikal ini dengan memainkan isu-isu lokal untuk mencapai tujuan global (Schulze \& Liow, 2018). Inilah tahap awal proses swa-radikalisasi, ketika ide radikal bertemu dengan isu yang paling dekat dengan lingkungan pengguna media sosial yang di dalam dirinya telah terdapat potensi radikal.

\section{Swa-Radikalisasi di Sosial Media}

Tujuan utama kelompok radikal dalam menyebarkan informasi melalui media online adalah untuk tujuan propaganda, radikalisasi, dan rekrutmen. Mereka mampu mengembangkan daftar calon atau simpatisan yang potensial melalui kelompok atau grup online. Pada praktiknya media sosial memungkinkan kelompok radikal untuk menggunakan strategi penargetan yang dikenal sebagai narrowcasting. Narrowcasting bertujuan menyebarkan pesan-pesan pada segmen tertentu dari publik sesuai dengan nilai, preferensi, atribut demografi, atau kecenderungan tertentu. Kunjungan ke situs-situs tertentu, video, atau obrolan online, gambar, seruan, dan informasi disesuaikan untuk 
dicocokkan dengan profil kelompok sosial tertentu. Metode-metode ini memungkinkan kelompok radikal untuk menargetkan pengguna media sosial yang berusia muda.

Dengan segala kelebihan media sosial, maka tidak mengherankan jika kelompokkelompok radikal menggunakan media sosial yang populer untuk merekrut para pendukung. Selain aplikasi media sosial ini tidak berbayar juga penyensoran masih cukup sulit untuk dilakukan. Satu hal yang paling penting adalah anak muda cenderung mempercayai informasi yang mereka baca atau dengar di jejaring sosial atau di situs-situs mikro blogging. Kepercayaan terhadap informasi atau pesan dari kelompok radikal yang tersebar dan berlimpah ini dapat memengaruhi perspektif pengguna terhadap lingkungan apalagi bila informasi ini didesain agar tampak valid dan meyakinkan. Hal ini terjadi disebabkan oleh fenomena yang dikenal sebagai "efek halo"; yaitu efek ketika seseorang membuat penilaian positif secara keseluruhan dari seseorang atau produk berdasarkan satu karakteristik positif tertentu saja.

Seperti diketahui bahwa propaganda akan sangat efektif jika melibatkan sisi emosional manusia. Itulah mengapa kelompok-kelompok radikal ini menggunakan desain multimedia yang dikelola dan dikurasi dengan baik ke dalam buletin online, majalah, dan unggahan media sosial mereka. Banyak kelompok bahkan mengembangkan permainan online yang melibatkan banyak pemain, dan secara secara gratis melalui platform game online. Permainan ini dominan mengandung kekerasan dan yang terpenting memungkinkan pengguna untuk menampilkan versi ideal dari diri mereka sendiri yang diaplikasikan dalam bentuk avatar. Efeknya pemain merasakan kebanggaan dan rasa kebersamaan dalam sebuah komunitas saat berperang dengan anggota komunitas lainnya.

Seiring waktu, pengalaman dan informasi yang didapatkan melalui media sosial dapat memengaruhi harapan pengguna tentang bagaimana mereka ingin hidup. Jika mereka merasa bahwa harapan ini tidak terpenuhi dalam kehidupan sehari-hari mereka, pengguna akhirnya menjangkau kelompok-kelompok radikal ini atau sebaliknya, menanggapi penjangkauan mereka untuk menjadi bagian dari apa yang mereka lihat 
sebagai tujuan besar, dan itu dianggap sebagai sebuah kesempatan untuk melakukan sesuatu yang berharga.

Fenomena lain yang saat ini meningkat sebagai akibat dari pesan kelompok radikal ini melalui media sosial adalah aksi lone-wolf terrorist (Jegho, 2017; Kapoor, 2017). Dalam dua tahun terakhir telah terjadi lima serangan oleh lone-wolf terrorist. Tuduhan ini didukung oleh bukti kuat bahwa ada proses swa-radikalisasi sebelum pelaku melakukan tindakan mereka. Pelaku terkena pesan radikal melalui internet dan media sosial dan kemudian menjalankan misi tanpa perintah dari siapa pun (Chan, 2016). Meskipun lonewolf terrorist ini bertindak tanpa pengawasan dari siapa pun, dan tidak berafiliasi dengan kelompok mana pun, ini perlu menjadi perhatian khusus karena tindakan mereka merupakan dampak dari penggunaan internet dan media sosial yang memberikan manfaat tidak langsung kepada kelompok-kelompok Islam radikal.

Setidaknya ada lima penyebab internet dituduh memainkan peran penting dalam mempromosikan radikalisme (Inos \& Reading, 2013); 1. Internet menciptakan lebih banyak peluang, 2. Internet bertindak sebagai 'ruang gema,' 3. Internet mempercepat proses radikalisasi, 4. Internet memungkinkan radikalisasi terjadi tanpa kontak fisik, dan 5. Internet meningkatkan peluang untuk swa-radikalisasi. Kemunculan teknologi baru berpotensi berfungsi sebagai kekuatan pengganda bagi teroris. Misalnya internet memungkinkan para aktivis yang memiliki ide untuk beroperasi atas inisiatif mereka sendiri tanpa arahan dari sebuah organisasi formal, ada kecenderungan yang menunjukkan peningkatan prevalensi lone-wolf terrorist oleh individu yang tidak terafiliasi dan dalam sel-sel yang kecil (Michael, 2014).

Terkait dengan swa-radikalisasi di kalangan pelajar dan mahasiswa, sebuah data menarik yang ditunjukkan oleh Survei Nasional tentang Sikap Keagamaan di Sekolah dan Universitas di Indonesia yang dilakukan oleh Pusat Studi Islam dan Masyarakat (PPIM) UIN Jakarta menyatakan bahwa, siswa yang tidak memiliki akses internet memiliki pendapat yang lebih moderat dibandingkan dengan mereka yang memiliki akses internet. Fakta yang cukup memprihatinkan melihat hasilnya, yaitu 51,1 persen siswa 
Muslim menunjukkan kecenderungan tidak bertoleransi terhadap minoritas. Selanjutnya, 58,5 persen responden mahasiswa memiliki pandangan agama pada pendapat radikal (Umam, 2017).

Penggunaan jaringan virtual, seperti media sosial sebagai instrumen radikalisasi dan rekrutmen online, akan membangkitkan simpati dari individu yang merasakan kondisi yang mendorong solidaritas, seperti kemiskinan, ketidakseimbangan sosial, dan frustrasi politik. Hughes \& Micklaucic (Hughes \& Miklaucic, 2016) menyebutkan orang-orang ini akan dipindahkan untuk meningkatkan akses mereka ke situs, ruang obrolan, jurnal online, streaming video propaganda, dan berbagai media online lainnya. Simpati ini dapat berkembang menjadi dukungan ketika intensitas akses online terus berlanjut, dan hubungan lebih intim dengan individu atau kelompok lain yang berbagi basis solidaritas yang sama dan simpati untuk kelompok radikal dan teroris. Dukungan ini dapat berupa donasi, sumber daya personel, atau jaringan keamanan yang diperlukan untuk pengembangan gerakan radikal.

Secara global, ISIL (Negara Islam Irak dan Levant) telah menunjukkan strategi komunikasi yang canggih dan praktis dalam menggunakan media online untuk menyebarkan propaganda multidimensi. Mereka telah menguasai platform media sosial dan telah menarik jaringan dukungan global yang mengartikulasikan, memperkuat dan mengedarkan kekerasan pesan-pesan ekstrimis di seluruh dunia. ISIL secara strategis merekrut pria dan wanita muda di seluruh dunia, menggunakan internet, majalah online, sebagian besar melalui media sosial, termasuk Facebook, YouTube, Twitter, dan Instagram (Liang, 2015).

Di sisi lain, skeptisisme tentang kemungkinan internet memiliki peran dalam ekstremisme kekerasan bukanlah sesuatu yang baru. Sebagian orang berpendapat bahwa peran Internet tidak banyak terkait dengan radikalisme. Namun, skeptisisme atas peran Internet dalam tindakan kekerasan dan terorisme dibantah oleh fenomena lone-wolf terrorist yang dimulai dengan swa-radikalisasi (Conway, 2017; Danzell \& Maisonet Montañez, 2016). Sebaliknya, munculnya teknologi baru berpotensi berfungsi sebagai kekuatan pengganda teroris. Ada tren yang terlihat menunjukkan peningkatan prevelance 
serangan lone-wolf terrorist yang dilakukan oleh individu yang tidak terafiliasi dengan organisasi manapun dan dalam bentuk sel-sel kecil. (Michael, 2014)

Ancaman lone-wolf terrorist yang diradikalisasi di internet atau melalui pengalaman perang di Suriah atau Irak semakin menjadi tren di seluruh dunia (Awan, 2017; Klausen, 2015). Sel ISIS dan Hizbut Tahrir di Indonesia dianggap sebagai sumber penyebaran cerita "jihadis inspirasional" yang dapat memancing sentimen keagamaan (Barrett \& NSDS, 2017).

Aksi teror teroris tunggal serigala cenderung melemahkan kekuatan destruktifnya daripada aksi teror yang dilakukan oleh anggota kelompok tertentu. Ini karena pelaku melakukan tindakan berdasarkan pengalaman pribadi atau tutorial dari internet (Alakoc, 2017; Aly, Macdonald, Jarvis, \& Chen, 2017). Namun, teror lone-wolf terrorist tidak boleh diremehkan. Para pelaku putus asa dan siap melakukan apa saja, termasuk mengorbankan hidupnya demi ideologi yang ia yakini.

Pada kenyataannya, secara praktik hampir tidak mungkin untuk memutuskan kelompok-kelompok radikal dari internet. Melakukan penyensoran berlebihan pada media sosial juga mengancam hak privasi pengguna, juga mengancam kebebasan berbicara dan berpendapat yang dijamin oleh undang-undang. Sebaliknya, program kontra-radikalisasi juga menggunakan kampanye berbasis internet untuk menantang ideologi dan klaim kelompok-kelompok radikal.

Sebuah pendapat atau perspektif akan menjadi lebih ekstrim jika kita hanya berinteraksi dengan orang lain yang mendukung sudut pandang kita. Tetapi proses yang dikenal sebagai polarisasi kelompok ini sebenarnya dapat dicegah. Internet adalah pasar di mana berbagai ide yang berbeda bersaing dan berkompetisi. Berbagi perspektif yang beragam tentang topik-topik seperti identitas, agama, dan kekerasan dengan orang-orang yang tenggelam dalam pesan-pesan sepihak kelompok-kelompok radikal dapat mencegah mereka untuk berpendapat ke posisi atau perspektif yang lebih ekstrim.

Ketika menyajikan apa yang disebut narasi balik ini, penting untuk mengakui keluhan kelompok-kelompok yang berbeda dalam masyarakat, sambil menyarankan strategi tanpa kekerasan untuk mengatasi permasalahan mereka. Mereka yang 
mengkomunikasikan pesan-pesan alternatif juga harus dihargai oleh pendukung potensial atau kelompok radikal yang ada termasuk oleh tokoh atau mantan militan yang paling berpengaruh.

Sebuah organisasi di Kanada yang bernama Extreme Dialog misalnya, memproduksi video dokumenter mantan anggota kelompok radikal, keluarga, teman, dan korban mereka. Video-video tersebut menunjukkan bagaimana kehidupan orang-orang terpengaruh secara dramatis oleh radikalisasi kekerasan, proyek ini bertujuan untuk merangsang pemikiran dan diskusi kritis.

Di Inggris, sebuah yayasan bernama Quilliam Foundation berperan aktif di media sosial untuk mempromosikan Islam yang demokratis dan non-radikal. Pendiri yayasan tersebut bernama Maajid Nawaz menggunakan Twitter dan Instagram untuk berbagi ide pluralistik tanpa merendahkan Islam. Pekerjaan organisasi-organisasi ini menunjukkan bahwa taktik yang untuk mencegah individu untuk bergabung dengan kelompok radikal, juga dapat diterapkan untuk melawan radikalisasi online. 


\section{Kesimpulan}

Perkembangan aplikasi internet khususnya media sosial berpengaruh pada pola rekrutmen dan penyebaran paham radikal. Ia ibarat alat multiguna yang bisa digunakan untuk belajar dari seseorang, kelompok atau untuk belajar sendiri secara otodidak. Swaradikalisasi sebenarnya bisa dicegah oleh pihak terkait seperti Kementerian Kominfo dengan melakukan pengawasan ketat terhadap konten yang disebarluaskan melalui aplikasi media sosial. Di sisi lain pengguna media sosial juga perlu terbuka dan peduli terhadap paham kekerasan yang suatu saat akan merusak sendi kehidupan bermasyarakat. Mereka perlu paham atas syarat-syarat ketat yang diberikan pemerintah terhadap pihak provider dan operator aplikasi media sosial.

Keluarga adalah filter pertama dan utama yang berperan besar untuk mengatasi swa-radikalisasi dengan memberikan arahan tentang moderasi Islam. Pengetahuan tentang bahaya ekstrimisme dan radikalisasi melalui jaringan internet perlu disampaikan sejak dini. Sangat penting untuk terlibat secara terus-menerus dengan anak dalam menggunakan internet untuk mengingatkan tentang potensi bahaya internet yang lain. Mendampingi anak remaja dalam mengakses juga penting untuk mengetahui dan mempelajari website yang mereka kunjungi, termasuk pilihan aplikasi yang mereka gunakan. Pengetahuan tentang cara menggunakan pengaturan privasi dan fitur pelaporan termasuk bagaimana memblokir seseorang dan bagaimana menjaga kerahasiaan informasi misalnya di Facebook dan Twitter juga penting. Beri tahu mereka untuk berpikir sebelum menulis atau mengunggah suatu informasi. Gunakan fitur kontrol orang tua untuk memfilter, membatasi konten yang tidak pantas dan memantau apa yang dilakukan anak secara online. Penyedia layanan internet juga wajib menyediakan berbagai paket yang disertai dengan fitur tertentu untuk membantu keluarga tetap aman dalam berinternet. 


\section{Referensi}

Alakoc, B. P. (2017). Competing to Kill: Terrorist Organizations Versus Lone Wolf Terrorists. Terrorism and Political Violence, 29(3), 509-532. https://doi.org/10.1080/09546553.2015.1050489

Andriadi, F. (2017). Partisipasi Politik Virtual: Demokrasi netizen di Indonesia. Jakarta Selatan: RMBOOKS.

Andriyani, N. L., \& Kushindarti, F. (2018). Respons Pemerintah Indonesia dalam Menghadapi Perkembangan Gerakan Islamic State Di Indonesia. Jurnal Penelitian Politik, 14(2), 223-238.

APJII. (2017). Survei Penetrasi dan Perilaku Pengguna Internet di Indonesia Tahun 2017. Retrieved February 24, 2018, from https://apjii.or.id/content/read/39/342/Hasil-SurveiPenetrasi-dan-Perilaku-Pengguna-Internet-Indonesia-2017

Awan, I. (2017). Cyber-Extremism: Isis and the Power of Social Media. Society, 54(2), 138-149. https://doi.org/10.1007/s12115-017-0114-0

Candra, B. D. A. (2017). Media Literasi Dalam Kontra Propaganda Radikalisme dan Terorisme Melalui Media Internet. Jurnal Prodi Perang Asimetris, 3(1), 17.

Chan, F. (2016, October 27). Indonesia sees more lone-wolf terror attacks. Retrieved April 22, 2018, from https://www.straitstimes.com/asia/se-asia/indonesia-sees-more-lonewolf-terror-attacks

Conway, M. (2017). Determining the Role of the Internet in Violent Extremism and Terrorism: Six Suggestions for Progressing Research. Studies in Conflict \& Terrorism, 40(1), 77-98. https://doi.org/10.1080/1057610X.2016.1157408

Heickerö, R. (2014). Cyber Terrorism: Electronic Jihad. Strategic Analysis, 38(4), 554565. https://doi.org/10.1080/09700161.2014.918435

Hughes, M., \& Miklaucic, M. (2016). Impunity: Countering Illicit Power in War and Transition. National Defense University, Center for Technology and National Security Policy.

Inos, V. B., \& Reading, A. (2013). Radicalization In Digital Era; the use of internet in 15 cases of terrorism and extremism. RAND.

IPAC. (2018). After Ahok: The Islamist Agenda in Indonesia (Electoral Violence No. 44) (p. 28). Institute for Policy Analysis of Conflict (IPAC). Retrieved from http://understandingconflict.org/en/conflict/read/69/After-Ahok-The-Islamist-Agenda-inIndonesia 
Ismail, N. (2016, April 12). Memburu Santoso, Menyibak Konflik Poso, DW Indonesia. Retrieved March 21, 2018, from http://www.dw.com/id/memburu-santoso-menyibakkonflik-poso/a-19178840

Jegho, L. (2017, July 5). Beware of 'Lone Wolf' Terrorists, Says Senior Minister Wiranto. Retrieved April 23, 2018, from http://www.globalindonesianvoices.com/30671/beware-of-lone-wolf-terrorists-saysenior-minister-wiranto/

Kapoor, K. (2017, December 29). Indonesia to add hundreds of counter-terrorism police to monitor IS. Reuters. Retrieved from https://www.reuters.com/article/us-indonesiasecurity/indonesia-to-add-hundreds-of-counter-terrorism-police-to-monitor-isidUSKBN1ENOWQ

Klausen, J. (2015). Tweeting the Jihad: Social Media Networks of Western Foreign Fighters in Syria and Iraq. Studies in Conflict \& Terrorism, 38(1), 1-22. https://doi.org/10.1080/1057610X.2014.974948

Michael, G. (2014). Counterinsurgency and Lone Wolf Terrorism. Terrorism and Political Violence, 26(1), 45-57. https://doi.org/10.1080/09546553.2014.849912

Muthohirin, N. (2015). Radikalisme Islam dan Pergerakannya di Media Sosial. Jurnal Afkaruna, 11(2), 240-259.

Samuel, T. K. (2016). Radicalisation in Southeast Asia: a selected case study of DAESH in Indonesia, Malaysia and the Philippines. Kuala Lumpur, Malaysia: Southeast Asia Regional Centre for Counter-Terrorism (SEARCCT), Ministry of Foreign Affairs.

Schulze, K. E., \& Liow, J. C. (2018). Making Jihadis, Waging Jihad: Transnational and Local Dimensions of the ISIS Phenomenon in Indonesia and Malaysia. Asian Security, 118. https://doi.org/10.1080/14799855.2018.1424710

Selamat, G. (2016, January 12). Kiblat Radikalisme Mengapa Mujahidin Indonesia Timur (MIT) Menjadi Sentral dari Gerakan Jaringan Kelompok Terduga Teroris di Indonesia? Retrieved January 15, 2018, from http://republika.co.id/berita/koran/teraju/16/01/12/o0tyga1-kiblat-radikalisme-mengapamujahidin-indonesia-timur-mit-menjadi-sentral-dari-gerakan-jaringan-kelompok-terdugateroris-di-indonesia

Siagian, B. D. O., \& Sumari, A. D. (2015). Radicalism Discourse Analysis on Online Sites in Indonesia. Jurnal Pertahanan, 1(2), 67-92.

Singh, D. (2009). Responses to Terrorism in Southeast Asia. Journal of Policing, Intelligence and Counter Terrorism, 4(1), 15-28.

https://doi.org/10.1080/18335300.2009.9686921 
Umam, S. (2017). Survey Nasional tentang Sikap Keberagamaan di Sekolah dan Universitas di Indonesia. (Research) (p. 36). Jakarta: Pusat Pengkajian Islam dan Masyarakat (PPIM) UIN Jakarta.

Ward, I., \& Cahill, J. (2007). Old and new media: Blogs in the third age of political communication. Australian Journal of Communication, 34(3), 1-21.

Weimann, G. (2014). New terrorism and new media. Commons Lab of the Woodrow Wilson International Center for Scholars Washington, DC.

Wood, A. F., \& Smith, M. J. (2005). Online communication: linking technology, identity, and culture (2nd ed). Mahwah, N.J: Lawrence Erlbaum Associates. 